\title{
Alleviation of cisplatin-induced nephrotoxicity in rats by aqueous extract of Salvia officinalis leaves
}

\author{
Kawa Dizaye \\ Department of Pharmacology, College of Medicine, Hawler Medical University, Irbil

$$
\frac{\text { Received }}{22.2 .2012} \quad \frac{\text { Accepted }}{17.5 .2012}
$$

\section{ABSTRACT}

Objectives: To evaluate the protective effects of the aqueous extract of Salvia officinalis leaves against nephrotoxicity induced by cisplatin in rats.

Methods: Albino rats were divided into three groups, each group consist of six rats. Group I treated with vehicle (distilled water) was kept as a control. Group II injected with a single dose of cisplatin (12 mg/kg body weight; i.p.). Rats in Groups III were received a single daily dose of aqueous extract of S. officinalis $100 \mathrm{mg} / \mathrm{kg}$ (P.O.), for 7 days. On the seventh day, cisplatin $(12 \mathrm{mg} / \mathrm{kg}$ body weight; i.p. was administered half an hour after the last dose of the plant extract. The rats in all groups were sacrificed $72 \mathrm{~h}$ after treatment. Renal injury was assessed using serum biochemical markers (creatinine and urea).

Malondialdehyde (MDA) concentration was measured as a marker of lipid peroxidation.The renoprotecive activity of S. officinalis was supported by histopathological studies of the kidney.

Results: Aqueous extract of S officinalis leaves significantly protected rat kidneys from cisplatin-induced histopathological changes. This extract also normalized cispaltin induced increases in serum creatinine and blood urea. In vitro studies revealed that the $\mathrm{S}$ officinalis leaf extract possessed significant oxidative radical scavenging activities.

Conclusion: Both biochemical findings and histopathological evidence showed the renoprotective potential of aqueous extract of $\mathrm{S}$. officinalis leaves against cisplatininduced oxidative stress and renal dysfunction in rats.

Key Words: Cisplatin, nephrotoxicity, extract of Salvia officinalis.

الخهف: دراسة التأثير الوقائي للمستخلص المائي لأوراق نبات Saliva officinalis للتسمم الكلوي بعقار

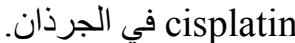
طرق العمل: قسمت جرذان بيضاء الى ثلاثة مجاميع، كل مجمو عة مكونة من ستة جرذان. عوملت الهجمو عة الأولى الهي بمادة التخفيف (ماء مقطر ) كمجو عة سيطرة. أما المجمو عة الثانية فقد نم حقنها بعقار

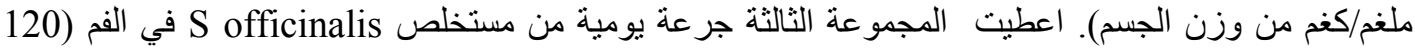

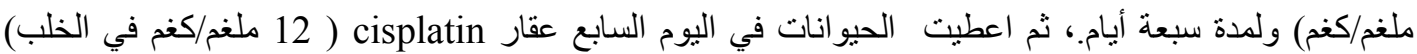
بنصف ساعة بعد اخر جرعة من المستخلص النباني. وقتلت جيع الحيو انات بعد 72 ساعة من المعاملة. وتم قياس

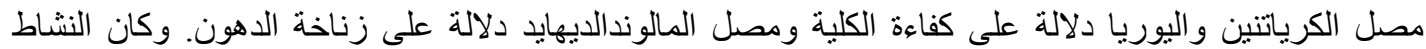

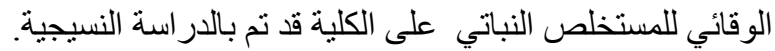

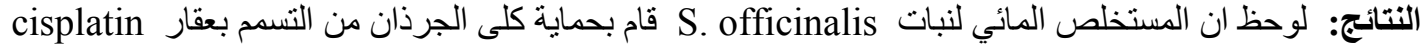

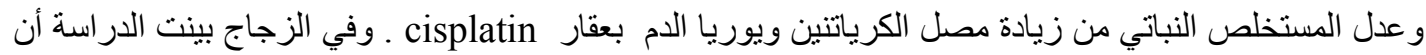

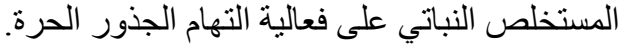

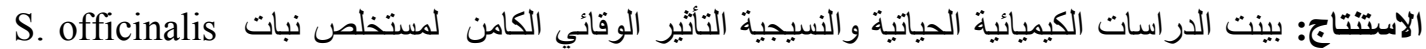
ضد الإجهاد ألتأكسدي و الأذى الكلوي لعقار cisplatin. 
M edicinal and poisonous plants always play an important role in the health among people all over the world. However, it has been estimated that only 6-8\% of the world's flora (approximately 250000 plants) and less than $10 \%$ of the organic constituents are known and have been investigated chemically, and $90 \%$ remains for discovery and investigations ${ }^{1}$. Medicinal plants have various effects on living systems. Some are sedatives, analgesics, antipyretics, antibacterials, antivirals antiprotozoals, cardioprotectives, hepatoprotective and nephroprotective agents ${ }^{2}$.

For centuries, many herbs have been used as natural remedies for the prevention and/or treatment of kidney diseases. Various herbs and herbal products are believed to have nephroprotective effects and widely used in clinical practice in many parts of the world, for example Silybum marianum attenuated nephrotoxicity induced by gentamicin in $\operatorname{dog} \mathrm{s}^{3}$.

Aqueous extract of Kalanchoe pinnata leaves significantly protects rat kidneys from gentamicin-induced histopathological changes in rats ${ }^{4}$. Salviae Radix Extract exerts a protective effect against renal cell injury induced by cisplatin, and its effect might be attributed to its antioxidant action ${ }^{5}$.

The name Salvia officinalis derives from the Latin 'salveo', which means to be saved. Salvia is a perennial herbaceous to shrubby herb growing up to $50 \mathrm{~cm}$ in height ${ }^{6}$. Herb is highly regarded for its healing qualities.. Salvia officinalis has a very long history of effective medicinal use The ancient Greeks used it to treat consumption, ulcers and snake bites, and is an important domestic herbal remedy for disorders of the digestive system $^{7}$. Its antiseptic qualities make it an effective gargle for the mouth where it can heal sore throats, ulcers etc. The leaves applied to an aching tooth will often relieve the pain ${ }^{8}$.

The leaf of $\mathrm{S}$. officinalis has antihistaminic activity which was not associated with anticholinergic activity. It had antifungal effects against Candida albicans ${ }^{9}$.

The present study was performed to evaluate the protective effects of the aqueous extract of Salvia officinalis against nephrotoxicity induced by cisplatin in rats.

\section{Materials and methods}

\section{Experimental animals}

Male waster albino rats weighing 150 $200 \mathrm{~g}$ were kept in the animal house of College of Medicine, Hawler Medical University. The room temperature was maintained at $25{ }^{\circ} \mathrm{C}$. A $12 \mathrm{hr}$ light/dark cycle was set. Rodent food rich in nutrient and tap water were used as bedding.

The animals were divided into three groups, each group consist of six rats. Group I was treated with vehicle (distilled water) and kept as control. Group II injected with a single dose of cisplatin (12 mg/kg body weight; i.p.). Group III received a single daily dose of aqueous extract of $\mathrm{S}$. officinalis (100 mg/kg body wt; p.o), for 7 days. Cisplatin (12 mg/kg body weight; i.p. was administered half an hour after the last dose of the plant extract. Rats in 
all groups were sacrificed $72 \mathrm{~h}$ after treatment.

\section{Blood samples}

Blood samples (1-2 ml) were collected from the rats in sterilized dry centrifuge tubes after carotid bleeding and allowed to coagulate for $30 \mathrm{~min}$ at $37{ }^{\circ} \mathrm{C}$. Serum was separated at 2500 rpm for $10 \mathrm{~min}$ and subjected to biochemical investigations.

Measurement of hepatocellular enzyme levels in serum

Serum creatinine, urea and Malondialdehyde (MDA) concentration were determined using a standard clinical automatic analyzer (Beckman, Brea, CA).

\section{Histological examination of kidney}

Anatomy of the kidney was studied immediately after sacrificing the animals. The kidney was excised from the animals and washed with normal saline. The materials were fixed in $10 \%$ buffered neutral formalin for 48 $\mathrm{hr}$ and with bovine solution for $6 \mathrm{~h}$ and processed for paraffin embedding. Sections of $5 \mathrm{~mm}$ thickness were taken using a microtome, processed in alcohol-xylene series and stained with special stain PAS (periodic acid Schiff) Bankroft $1996^{10}$ and subjected to histopathological examination.

\section{Plant preparation}

An aqueous extraction of Salvia officinals was prepared by using of ultrasonication $^{11}$. A sample of $50 \mathrm{~g}$ of powdered herb was suspended in 1000 $\mathrm{ml}$ distilled water in a glass beaker, mixed well, sonicated for $2.5 \mathrm{hr}$, in an ultrasonic machine bath (Decon FS 200 Frequency Sweep) at a constant temperature $\left(25{ }^{\circ} \mathrm{C}\right)$. Extract was separated by simple filtration, residual material washed with $20 \mathrm{ml}$, of pure water, the soluble extracts were concentrated ten-folds by rotary vacuum evaporator at $45-50 \quad{ }^{\circ} \mathrm{C}$ preserved in refrigerator for further studies.

The entire plant of S. officinalis was sun dried for ten days before the final drying in an oven at $50{ }^{\circ} \mathrm{C}$ for 24 hours. The dried plants were powdered in both manual grinder and electric grinder. Fifteen grams of the S. officinalis powder were soaked with $350 \mathrm{~mL}$ of distilled water in a beaker and the mixture shaken on the laboratory bench for 24 hours before filtering. The filtrate was evaporated by hot-air oven treatment at $40-50{ }^{\circ} \mathrm{C}$. Appropriate weights of the residue were prepared in distilled water to obtain the various concentration used for the experiments.

Results were expressed as means \pm SE. Statistical analyses were carried out using ANOVA and Duncan test. Level of significance was set at $\mathrm{p}<$ 0.05 .

\section{Results and discussion}

In this study, compared to the control group the level of serum urea and creatinine in cisplatin-induced nephrotoxicity in rats were found to be significantly increased in rats treated only with cisplatin, whereas treatment with the aqueous extract of the leaves of S. officinlais found to protect the rats from such effects of cisplatin as shown in Table 1. 
Table 1. Serum creatinine and urea level in control, cisplatin and cisplatin with aqueous extract of S. officinalis rats

\begin{tabular}{|l|l|l|l|}
\hline Parameters & $\begin{array}{l}\text { Control } \\
\text { group }\end{array}$ & $\begin{array}{l}\text { Cisplatin } \\
\text { Group }\end{array}$ & $\begin{array}{l}\text { Cisplatin }+ \text { S. } \\
\text { officinalis group }\end{array}$ \\
\hline Urea $\mathrm{mg} / \mathrm{dl}$ & $43.3 \pm 3.22$ & $\begin{array}{l}56.8 \pm 4.34 \\
\mathrm{a}\end{array}$ & $\begin{array}{l}45.2 \pm 6.25 \\
\mathrm{~A}\end{array}$ \\
\hline Creatinin $\mathrm{mg} / \mathrm{dl}$ & $0.65 \pm 0.02$ & $1.24 \pm 0.12$ & $1 \pm 0.15$ \\
& $\mathrm{a}$ & $\mathrm{B}$ & $\mathrm{Ab}$ \\
\hline $\begin{array}{l}\text { Malondialdehyde } \\
\mu \mathrm{mol} / \mathrm{L}\end{array}$ & $0.74 \pm 0.018$ & $\begin{array}{l}2.51 \pm 0.0528 \\
\mathrm{~B}\end{array}$ & $\begin{array}{l}1.86 \pm 0.043 \\
\mathrm{Ab}\end{array}$ \\
\hline
\end{tabular}

Different letters indicate there is a significant difference at $\mathrm{P}<0.05$

The concentration of malondialdehyde (MDA) is observed to be significantly increased in the cisplatin-treated animals compared to the normal group. Administration of S. officinlais extract for 7 days before and a long with cisplatin decreased MDA to the normal level compared to cisplatin-treated animals (Table 1), this indicates the presence of antioxidant substances which protects the kidney damage via free radicals induced by cisplatin ${ }^{5}$.

To determine the morphologic changes of the kidney after cisplatin treatment, we performed histologic analyses of kidneys that were isolated from animals that survived to determine tubular necrosis using established histologic criteria $^{12}$.

Compared to the control group the measurements of the thickness of basement membrane in glomerular capillary and kidney tubules and PAS $+v e$ granules in distal convoluted tubule in rats treated with ip injection of cisplatin were significantly increased. In normal condition the basement membrane of glomeruli and renal tubules were normal $(1-2 \mu \mathrm{m})$, while in pathological conditions of renal diseases there was an increase in basement membrane thickness (3-5 $\mu \mathrm{m})$ with presences of PAS positive particles indicated that there will be damage to renal tissue which lead to an accumulation of glycoproteins within renal tubules ${ }^{13}$, as shown in Tables 2 and Figures 1 and 2 .

Cisplatin and its analogues are widely used in the chemotherapy of a variety of human malignancies including head, neck, ovarian testicular and lung cancers ${ }^{14}$. However, the use of these compounds is limited by their side effects, cisplatin appear to be directly toxic to the renal tubules, usually most severe in the proximal tubules. After a single injection of cisplatin, $28-36 \%$ of patients develop dose-dependent nephrotoxicity. Cisplatin has been shown to accumulate in the kidney to a greater degree than in other organs $^{15,16}$. 
Table 2. The effects of S. officinalis (PO) on the histological changes of kidney in cisplatin treated rats

\begin{tabular}{|l|l|l|l|}
\hline & Control & Cisplatin & $\begin{array}{l}\text { Cisplatin } \\
\text { officinalis }\end{array}$ \\
\hline $\begin{array}{l}\text { GBM } \\
(\mu \mathrm{m})\end{array}$ & $1.26 \pm 0.19$ & $3.29 \pm 0.32$ & $1.99 \pm 0.22$ \\
\hline TBM & $\mathrm{a}$ & $\mathrm{B}$ & $\mathrm{A}$ \\
$(\mu \mathrm{m})$ & $1.66 \pm 0.17$ & $3.71 \pm 0.42$ & $2.23 \pm 0.15$ \\
\hline PAS $+\mathrm{ve}$ & $\mathrm{a}$ & $\mathrm{B}$ & $\mathrm{Ab}$ \\
\hline & $0.05 \pm 0.04$ & $5.34 \pm 0.67$ & $2.26 \pm 0.23$ \\
& $\mathrm{a}$ & $\mathrm{B}$ & $\mathrm{Ab}$ \\
\hline
\end{tabular}

GBM $=$ Glomerular Basement Membrane

TBM $=$ Tubular Basement Membrane

PAS = Periodic acid Schiff reagent, special stain used for the staining of glycoproteins such as basement membrane components.

The different letters indicate there is a significant difference at $\mathrm{P}<0.05$

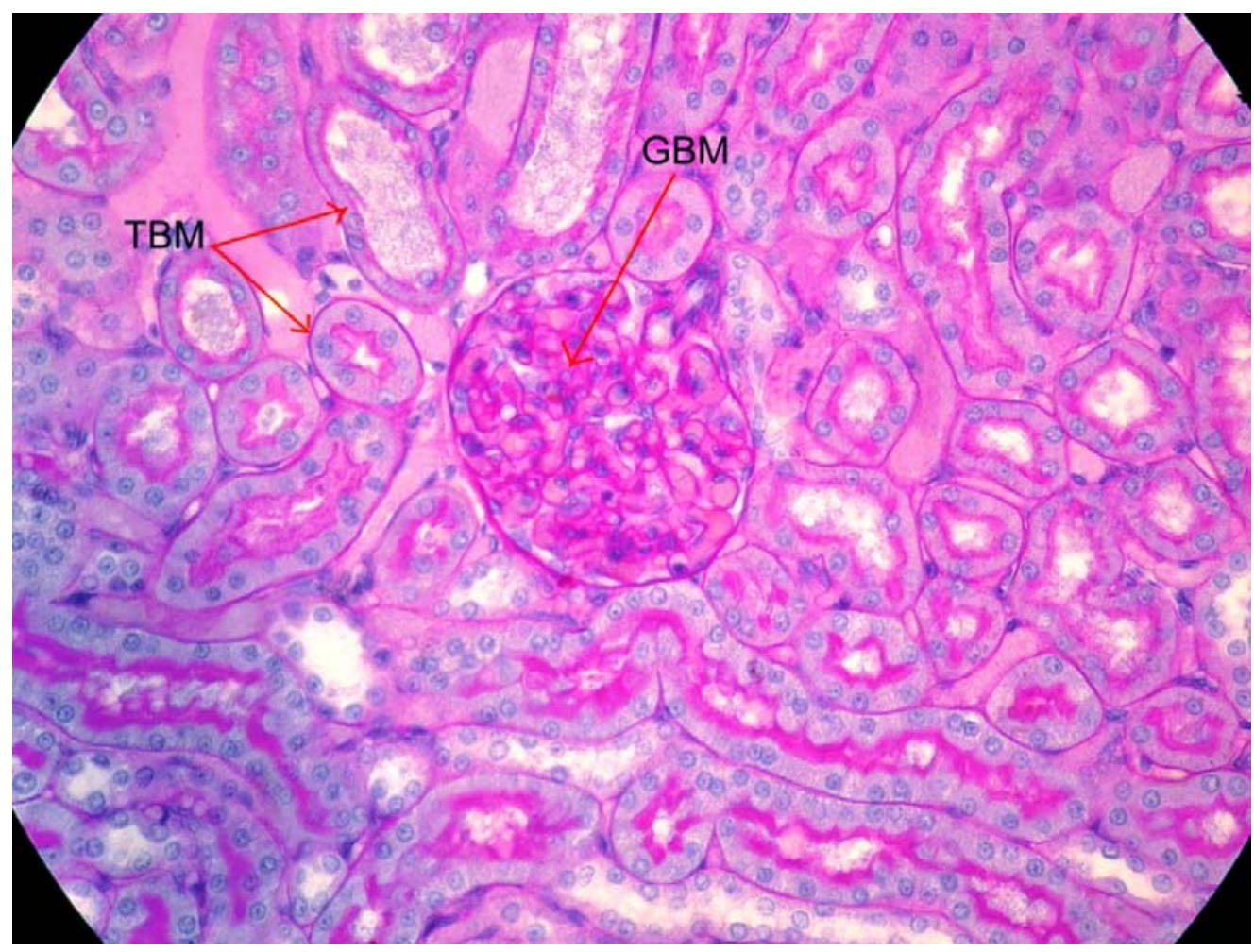

Figure 1. Renal cortex of normal rats stained by PAS. X100.

GBM $=$ Glomerular Basement Membrane

$\mathrm{TBM}=$ Tubular Basement Membrane 


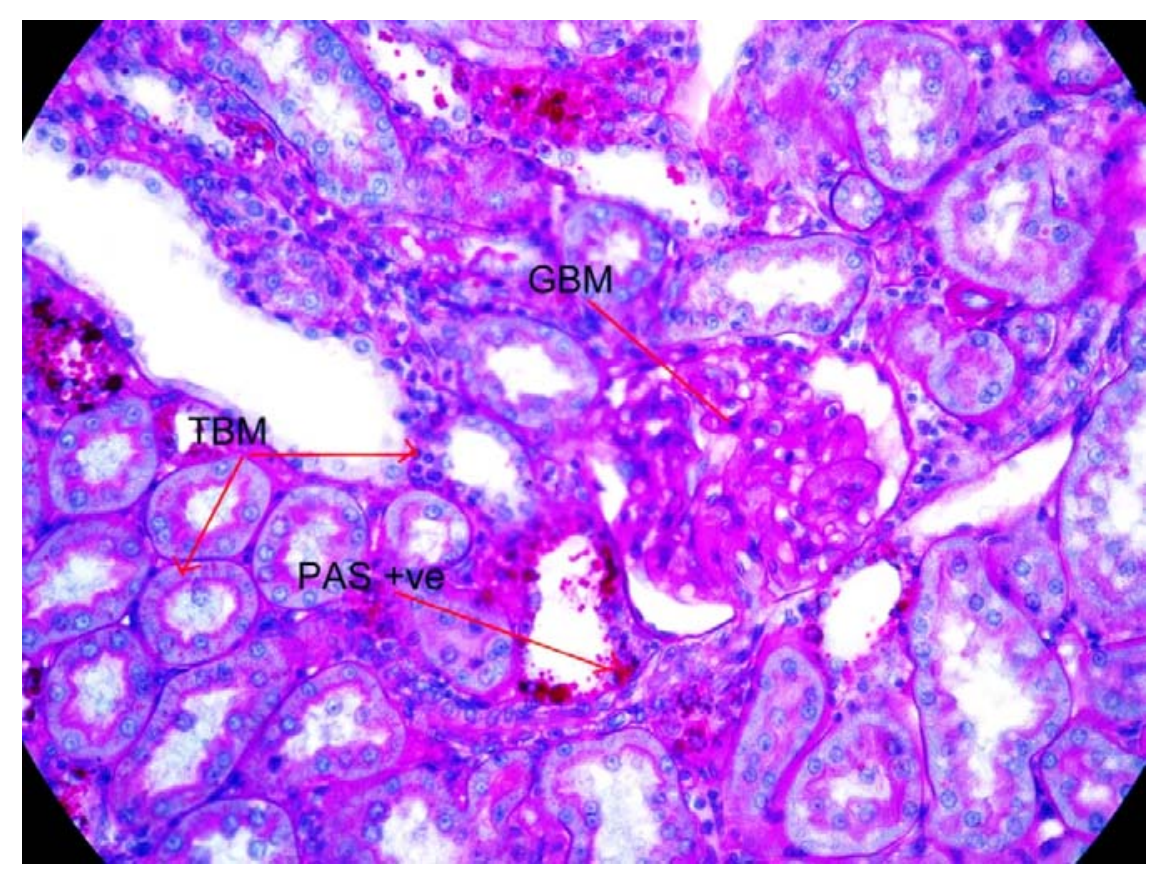

Figure 2. Renal cortex of rats treated with cisplatine stained by PAS. X100.

GBM $=$ Glomerular Basement Membrane

$\mathrm{TBM}=$ Tubular Basement Membrane

PAS $=$ Periodic acid Schiff reagent, special stain used for the staining of glycoproteins such as basement membrane components.

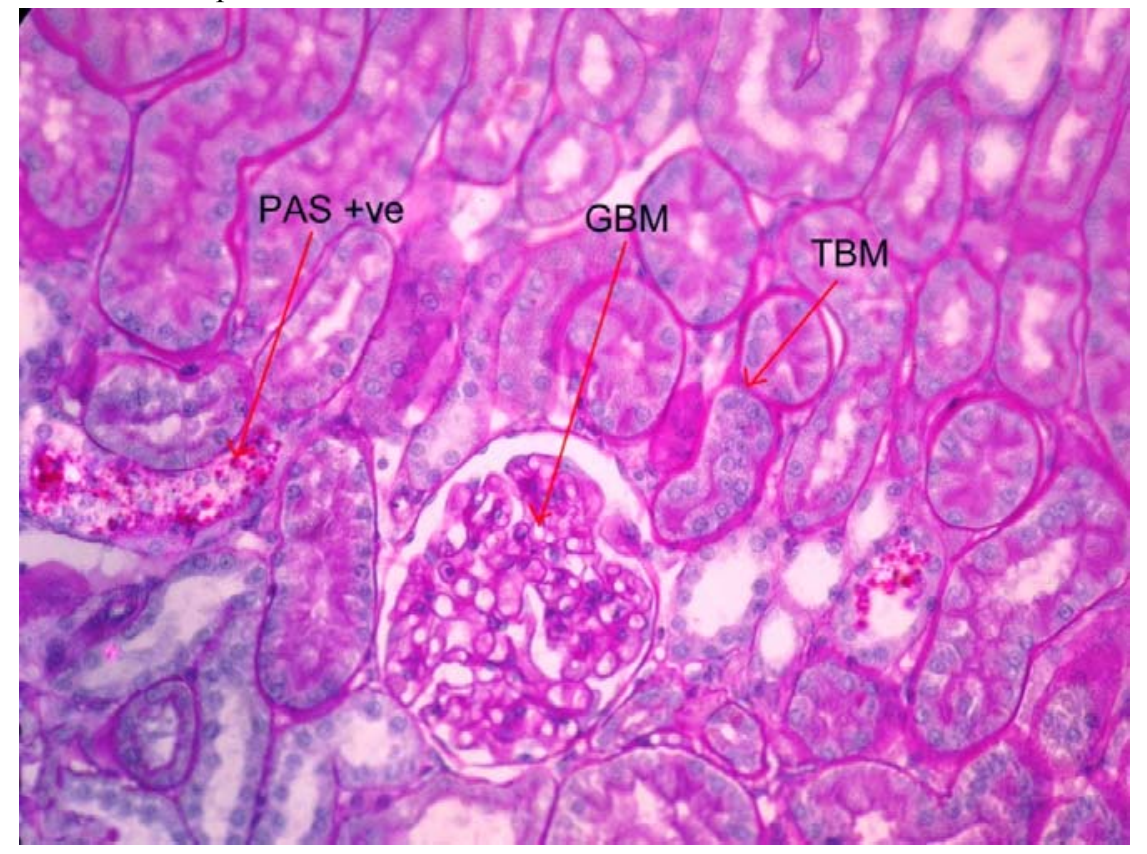

Figure 3. The effects of S. officinalis extract on the renal toxicity induced by cisplatin, stained by PAS. X100.

GBM $=$ Glomerular Basement Membrane

TBM $=$ Tubular Basement Membrane

PAS = Periodic acid Schiff reagent, special stain used for the staining of glycoproteins such as basement membrane components. 
The nephrotoxicity associated with cisplatin is well documented and constitutes a dose-limiting side effect of cisplatin therapy. Morphological and physiological studies have identified the renal tubule system as the site of maximum cisplatin damage, with the proximal tubules being most affected

The mechanism of the cisplatininduced cytotoxicity is not fully understood. It was shown that cisplatin is capable of binding to several cellular components, including membrane phospholipids, thiols, cytoskeletal microfilaments, proteins, RNA and $\mathrm{DNA}^{15}$. Apparently, this may involve more than one mechanism of cell death. Several lines of evidence indicate that free radicals are involved in the nephrotoxicity caused by cisplatin, and the damage is suggested to be the consequence of decreased renal anti- oxidant enzyme activity with enhanced lipid peroxidation. Administration of antioxidants has been shown to ameliorate cisplatininduced nephrotoxicity in animals ${ }^{16}$.

A significant decrease in the level of blood urea and creatinin were observed in cispaltin treated rats after administration of $\mathrm{S}$. officinalis extracts. In the present study, this reduction of blood urea seems to be due to its ability to reduce renal dysfunction. The stabilization of these renal parameters by the aqueous extract was a clear indication of the improvement of the functional status of the kidney, since most histological and histochemical changes seen before treatment with the extract were restored to nearly normal forms, such as a reduction in the thickness of glomerular and tubular basement membranes. The results of the present study showed that plant extracts bring back the progression of renal damage in cisplatin treated rats to near normal levels, this indicates that the protective effect of flavonoid in the plant extracts have repairing effects on the organ tissue $^{17}$. Moreover, there is a significant reduction in PAS +ve granule in distal convoluted tubules through decreasing rate of glycoprotein as shown in Tables 2 and Figure 3.

We suggest that the plant extract contains constituents having nephroprotective and antioxidant which acts in the kidney as a potent scavenger of free radicals to prevent the toxic effects of cisplatin.

In conclusion, both biochemical findings and histopathological evidence showed the renoprotective potential of aqueous extract of $\mathrm{S}$. officinalis against cisplatin-induced oxidative stress and renal dysfunction in rats.

\section{References}

1- Olaleye MT, Adegboye OO, Akindahunsi AA. Alchornea cordifolia extract protects wistar albino rats against acetaminopheninduced liver damage. African J Biotechnol 2006;5 (24):2439-45.

2- Prasenjit M, Mahua S, Parames C.. Aqueous extract of Terminalia arjuna prevents carbon tetrachloride induced hepatic and renal disorders. BMC Complementary and Alternative Medicine 2006, 6:33.

3- Varzi HN, Esmailzadeh S, Morovvati $\mathrm{H}$, et al. Effect of silymarin and vitamin $\mathrm{E}$ on gentamicin-induced nephrotoxicity 
in dogs. Vet $\mathrm{J}$ Pharmacol Ther. 2007;30 (5):477-81.

4- Gaurav VH, Chandragauda RP, Mahesh RP. Protective effect of Kalanchoe pinnata pers. (Crassulaceae) on gentamicininduced nephrotoxicity in rats. Indian J pharmacol 2007;39:4:20105.

5- Jeong JC, Hwang WM, Yoon $\mathrm{CH}$, Kim YK. Salviae Radix Extract Prevents Cisplatin-Induced Acute Renal Failure in Rabbits. Nephron 2001;88:241-6

6- Bartram T: Encyclopedia of Herbal Medicine, 1995;1st edn., Grace Publishers, Bournemouth.

7- Betsy C. Book of Salvias: Sages for Every Garden by, 1997; Timber Press.

8- Bown D. Encyclopaedia of Herbs and their Uses.1995; Dorling Kindersley, London.

9- Dizaye, K. The Pharmacological and Antimicrobial Studies of Salvia officinalis Infusion Vol. 2 No (2) 2005

10- Bancroft, JD, Alan, S, David, RT. Theory and practice of Histological techniques, 19964th ed. P:185, 282.

11-Djilani A, Legseir B, Soulimani R, Dicko A Youngs C. New extraction technique for alkaloid. J Brazilian Chem Soc 2006;17(3):518-2.

12-Sheena N, Ajith T A and Janardhanan K K : Prevention of nephrotoxicity induced by the anticancer drug Cisplatin, using Ganoderma lucidum, a medicinal mushroom occurring in South India. Current science, 2003 vol. 85, NO. 4, 25

13- Schrier RW, Wang W, Poole B, Mitra A: Acute renal failure: Definitions, diagnosis, pathogenesis, and therapy. J Clin Invest 2004;114:5-14,

14-Solez K, Morel-Maroger L, Sraer JD: The morphology of "acute tubular necrosis" in man: Analysis of 57 renal biopsies and a comparison with the glycerol model. Medicine (Baltimore) 1979; 58:362-76,

15-Gonzalez VM, Fuertes MA, Alonso C, Perez JM: Is Cisplatininduced cell death always produced by apoptosis? Mol Pharmacol 2001;59:657-63.

16-Lebwohl D, Canetta R: Clinical development of platinum complexes in cancer therapy: An historical perspective and an update. Eur J Cancer 1998;34:1522-34,

17-Dragan T, Milena T. Nikolova, Stephanie V, Jelena B, Stojanovi V B Veljkovi. Extraction of flavonoids from garden (Salvia officinalis L.) and glutinous (Salvia glutinosa L.) sage by ultrasonic and classical maceration J. Serb Chem Soc 2007; 72 (1):73-80. 